\title{
Bultmann's Thoughs:Demitologizationand Its Impact on the Contemporary Christianity Today
}

\author{
Stanley Kalalo, Antoni Bastian and David Ming
}

\section{ABSTRACT}

\begin{abstract}
Liberal theology was a characteristic that stood out in Bultmann's day. Several questions arise: Who is Rudolf Karl Bultmann? How did Bultmann and his thinking demotologi? What are Bultmann's works? How Demithologization and Its Impact on 21st Century Era Christianity? The solution is: (1) Bultman is a New Testament figure based on his form criticism. (2) The demotology says that the entire New Testament is a myth. Especially the stories about the Lord Jesus. He argued that the experiences of the Lord Jesus' ministry, his miracles, death, and resurrection, were stories fabricated by the early church. Biblical evangelicals believe in the invalidity of the Bible and all supernatural events that are recorded in the Bible, both the Old Testament, as well as the events of the preaching of the Word carried out by the Lord Jesus Christ and the Rulers, accompanied by a statement of power, is a truth that also makes sense. Christian faith, cannot accept unreasonable things.Bultmann'sdemitologization should not be taken as a theology, but as a discourse of seeking the truth with no clear origin, a thought for those who do not know God, namely vain thoughts, dark understanding.
\end{abstract}

Keywords: Bultmann, demitologization, hermeneutic.

\author{
Published Online: November 03,2021 \\ ISSN: $2736-5514$ \\ DOI: $10.24018 /$ theology.2021.1.6.4 \\ S. Kalalo \\ Sekolah Tinggi Teologi Abdi Gusti, \\ Indonesia. \\ (e-mail: stanley@abdigusti.ac.id) \\ A. Bastian \\ Sekolah Tinggi Teologi Abdi Gusti, \\ Indonesia. \\ (e-mail: bastianantoni9@gmail.com) \\ D. Ming* \\ Sekolah Tinggi Teologi Abdi Gusti, \\ Indonesia. \\ (e-mail:davidmingming3@gmail.com)
}

*Corresponding Author

\section{INTRODUCTION}

In 1884, on August 20, Rudolf Karl Bultmann was born in. As a great theologian of the 20th century Bultmann is widely known for sparking the idea of demythologizing the New Testament so that it is possible to separate the Christian Bible from mythological symbols [1]. Bultman studied theology at several universities. At the University of Marburg he studied under Wilhelm Herman whose theology was the basis of all Bultmann's theological thinking influenced by Johannes Weiss who was also from the University of Marburg. In 1908 Rudolf Bultmann became a professor at Marburg, where he became acquainted with Wilhelm Heitmuller who encouraged him to specialize in the History of Religions School [2].

He was a PB expert, a linguist, a philosopher who lived contemporaneously with Karl Barth, Paul Tilich, Deitric Bonhoeffer. At first, he was a member of the Karl Barth group, but for some reason (no clear explanation) then he went his own way. His Lectures on the New Testament and Mythology: The Problem of Demythologizing the New Testament Message, encouraged interpreters to replace traditional theology with the existential philosophy of Bultmann's colleague Martin Heidegger, an attempt to make the reality of Jesus' teachings more comprehensible to modern educated readers. Bultmann remains convinced that the stories of Jesus' life offer theology in story form. The lessons were taught in the mythical language known at the time. They should not be discarded but should be explained so that they can be understood for the present. Bultmann considers faith to be a present-day reality. For Bultmann, the people of the world always seem to be in a state of disillusionment and confusion. Faith must be an act of vital and firm will, not an effort to gather and glorify "ancient evidence" [3].

Bultmann's work in the field of theology was very influential and received a lot of attention from experts in his field and was quite productive as shown by the many works, he wrote. Among the theological works, especially concerning the interpretation of the New Testament, are The New Testament and Mythology, Theology of the New Testament, History and Eschatology: The Presence of Eternity, History of The Synoptic Tradition, Jesus Christ and Mythology, and Religion without Myth written with Karl Jaspers.

Bultmann's special ability in the field of the New Testament is what made him an influential theologian scholar in the 20th century, besides that he is also known as a philosopher, linguist, and historian. A philosopher who influenced Bultmann's philosophical thought was Martin Heidegger who was known for his existentialist philosophy, the two of them were friends from 1923 to 1928 so that from that friendship quite colored Bultmann's theology [4].

In the history of his career, he gave many lectures at the universities of Marburg, Breskau and Giessen. But the bulk of his academic career was spent as a New.Testament. at 
Marburg from 1921 until his retirement in 1951. He remained an honorary Professor until he ended his life in 1976. In the history of theology Bultman is better known for his demythology [5].

Liberal theology was a prominent characteristic of Bultman's time. Where they are very optimistic about their own abilities, as human beings who will progress (rationalism is highly emphasized). In this era also emerged a very famous thought written by Adolf Harnack about "what is christian?", in which Bultman was the one who wrote the introduction. This thought wants to challenge every theology student at that time, so that they can understand the theological situation in which they live, and not unanimously accept the views of hereditary traditions that are not necessarily true [6]. The study of the history of religions and their truths was something that was developing in the liberal tradition at that time (which had an influence on Bultman, and his thoughts in the future).

\section{Methods of Research}

The author uses a qualitative descriptive writing methodto describe Who is Rudolf Karl Bultmann? How did Bultmann and his demotology think? What is Bultmann's work? How is Demythology and its Impact on Christianity? [7].

\section{Results AND Discussion}

\section{A. Bultmann Thought Myth: Hermeneutics and Demythologyzing}

Demythology is the interpretation of passages of the Bible that are considered mythological by emphasizing the existential truths contained in the myth. According to Bultman, modern humans find it difficult to understand the message of the New Testament. The New Testament has a world view that is completely different from the modern view of the world (humans of the $19^{\text {th }}-20^{\text {th }}$ centuries). Modern humans can no longer accept that this reality is divided into 3 parts, the upper realm (heaven), the middle realm (the earth where humans and the meeting place of divine and demonic powers), and the underworld (hell). Modern humans don't believe in spirits and powerful powers anymore. Humans no longer believe in such myths [8].

Existentialism is an understanding that departs from human existence. According to Bultmann faith means "opening ourselves freely to the future". Faith is "an act of surrendering oneself to obediently assume responsibility, as well as a sense of freedom from being inwardly unaffected by the world". Apparently objective mythological statements have become existentialist statements about humans. Bultmann himself has admitted to replacing theology with anthropology, interpreting statements about God as statements about human life. "Then it is clear that if man wants to talk about God, he must speak about himself." [9].

According to Bultmann, miracles are not an important element in Christianity, but are only an element of skin culture, and not the main element. Thus, Bultmann's opinion is more severe: if Christians still think that the supernatural world can interfere with this world, then God is still considered as a rival to humans, then God's thinking is far from perfect. Belief in miracles prevents us from reaching the true concept of God. It is impossible for God to be an observable object in this world and believing in miracles is to objectify this supernatural ruler. Therefore, stories about miracles must be given a subjective understanding only. On Easter day, nothing may or may not happen to the body of Jesus, but there is a great change in the soul of the disciple. Previously, they were disillusioned with the punishment and crucifixion of Jesus, and they were afraid that the action of the Jewish police would continue so that later they too would be arrested. On Easter day, there was no resurrection of Jesus but the resurrection of the spirit of Jesus' disciples, they realized that the good news from Jesus remained valid and did not disappear with Jesus' death [10].

There are several materials and materials used by Bultmann to compile his theology in the form of: (1) historical criticism of liberal theology, (2) direction of word and faith in dialectical theology, (3) reformatory teachings on justification, (4) Martin Heidegger's philosophy of existence. In Bultmann's method is the application of Dasein's brilliant existential thoughts (substance and temporality) Heidegger. Everything is cooked in the "Being and Time" kitchen consistently and systematically into something new and has its own characteristics. Its purpose is to give direction to the question of believing (glauben) and understanding (verstehen). This means that Bultmann still bases his theology on dialectical theology, although on the other hand he also develops liberal theology on critical historical thought [11].

Hermeneutics is a science that tries to describe how a word or an event in the past time and culture can be understood and become existentially meaningful in the context of the present situation. This process, said Braaten, involves methodological rules applied in interpretation as well as epistemological assumptions about understanding. Meanwhile, Rudolf Bultman, as quoted in Abdul MoqsithGhazalli's writings, stated that the term hermeneutics is generally used to discriminate the attempt to span the gap between past and present. Which means, usually hermeneutics is used to bridge the gap between the past and the present [12]. The main task of hermeneutics is how to interpret a classical text or social reality in the past that was completely foreign to people who lived in a different time, place, and cultural atmosphere. In other words, hermeneutics always struggles with the problem of understanding the text in a broad sense, including historical events, symbols, and myths [13].

In the hermeneutic view, the world of social life is not only the world that is lived by individuals in society but is also an object of interpretation that arises because of that appreciation. Thus, in relation to the social sciences, hermeneutics is an interpretation or understanding of the world of life. Therefore, as a method of understanding, hermeneutics is very suitable to be applied to the human sciences (geitenwissenschaften) whose object is the expression of life (lebensaeusserung) including concepts, actions, and appreciation (erlebnis) of humans [14].

Central to the concept of demythologizing is Bultmann's stance, which finds two things in the New Testament, namely: a) the Christian gospel, and b) the mythical first 
century view of people. The essence of the gospel, by Bultmann called kerugma (Greek $=$ content that is preached), is the essence that cannot be narrowed down anymore. Modern people must confront that core and must believe in it. But modern people cannot accept the mythical framework that encloses the essence of the Bible. Therefore, theology must try to disentangle the message of kerugma from a mythical framework. As mentioned above, Bultman is better known as a New Testament. than being a theologian. In studying the Bible, he uses a literary form research approach or form criticism. He tried to analyze the stories of the Bible and categorize them in various types and forms. In this way he wanted to trace the earlier development of the Gospel accounts and their decline in function in the early church. Thus, he wanted to determine the historical truth of the Bible. Bultmann concluded that most of Jesus' recorded sayings did not come from himself, but from the lives of the ancient Christian congregations. He doubts that we who live today can know the outline of the life of Jesus. Bultman's description of Demythologization, can be said more as an attempt to believe and understand the Christian message in the perspective of modern times. His point is, he wants to make the Word of God something that modern people can understand, so that they can hear the word of God. Because according to him what covers the Word of God is the deep difference between the picture of the world of the New Testament. and a picture of the modern world.The picture of the modern world is determined by science and engineering, while the world of the New Testament. mystical. Modern humans can no longer accept that this reality is divided into three parts, namely: the upper realm (heaven), the middle realm (the earth where humans and the meeting place of divine and denomic powers) and the underworld (hell) [15].

Modern humans do not believe in spirits and supernatural powers. There are at least two things that prevent modern people from believing in the New Testament. world image. namely, (1) scientific knowledge of the universe and (2) modern man's paradigm of himself. [16] modern man must see himself no longer as a dualistic character, which is always open to supernatural power intervention. He must see himself as a unit, as an independent person. Therefore, it is not possible if the people are required to believe in the divine Spirit as something supernatural. Who enters the natural world, or believes in death as a punishment for sin, or believes in redemption in exchange for others, or in resurrection? Currently, no one expects that the journey of the universe and history will be disrupted by a supernatural power. Based on his three views on the Bible, Bultman strongly rejects the liberal search for the historical Jesus, namely: first, only a minimal knowledge of Jesus is possible, and that is clearly not sufficient to write a history of Jesus. Second, knowledge of the historical Jesus is not necessary. The Gospels need no stronger historical basis than the fact that Jesus lived and died. Third, attention to the historical Jesus is illegitimate. Paul's statement that we no longer know Jesus "according to the flesh" (i.e., physically / carnally), by Bultman means that Paul is no longer interested in the historical Jesus [17]. He also emphasized that the principle of reformation is justification by faith alone and not by history, (the principle of reformation is more accurately summarized as justification by Christ alone (the historical one)) which is accepted by faith.

For Bultman "myth" is a story that does not distinguish fact from non-fact in its content, and which dates to a prescientific era. The purpose of myth is to express man's understanding of himself, not to present an objective picture of the world. Myth uses parables and terms taken from this world to express beliefs about man's understanding of himself. For example, the so-called myth about the virgin birth of Jesus is an attempt to explain the meaning of Jesus to believers. They say that Jesus came to us as an act of God [18].

The cross of Christ has no meaning to indicate that Jesus bore sins for others. It only has an understanding as a symbol with humans taking on a new life, namely giving up all security in the world to get a new life that depends on the transcendent [19]. This view is almost the same as that of Sigmund Freud.

\section{1) Bultman's Works Career}

In the course of his career, Bultman has written many written works. However, in this case, the author will only list a few of his works, where these works are major works that have a wide influence, especially in the theological thought of the $20^{\text {th }}$ century, namely.

In 1926, Bultman published a booklet entitled Jesus and the Word, in which he had interpreted the Bible in existential terms. For him the problem was not something that Jesus did objectively outside of us or for us. Nor is it simply a matter of the objective word of God. Jesus is the preacher of the Word, which requires humans to make decisions, and enables us to "interpret our own existence" [20].

In 1941, New Testament studies took another turn, when Bultman distributed a paper on duplicating paper to a small group of friends entitled "New Testament and Mythology". If liberal theologians say that some events in the New Testament such as the birth of the virgin, the empty tomb, the resurrection and ascension of Jesus are mythical. Bultman goes to the extreme in saying that mythology is not limited to certain events; rather, the whole ethos and thought form in the New Testament is mythical. According to him, what we need now is to demythologize Christian messages, get rid of and reinterpret disturbing myths, so that the gospel can be presented in a pure manner. In 1958 in his book Geschicte und Eschatologie (history and eschatology), he argued that the meaning of history always lies in the present. Man's gaze must be directed to oneself, not to God and not to the world [21].

\section{B. Demythology and Its Influence on This Contemporay Christhian Worlds}

After we both pay attention for a moment to Bultman and his thoughts, it turns out that all of this is not something that does not have a worrying impact in the world of theology. But on the contrary, the thoughts that he has spawned have an impact on the theological world in Europe and Asia. Especially in the UK and the US, scholars, though they are "wary" of the teaching that is almost exclusively associated with Bultman's name, emphasize the limits of form criticism. But gradually they also accept the presupposition of form criticism [22]. 
In Japan, one of the young Professors in theology there recently commented that; "We no longer immediately accept what the New Testament says, just because the New Testament says so". We critically consider whether it is historically true or false what the New Testament says [23]. In Korea, especially over the last ten years, the influence of the Bultman methods has expanded in such a way. The methodology of form criticism has been warmly welcomed and used at various levels by new Testament scholars, such as Dr. Chun Kyung-Yun of Hankuk Theological Seminary, and recently by Prof. Mr. Chang-Hwan from Presbyterian Theological Seminary, Seoul [24].

\section{CONCLUSION}

Bultman is a New Testament figure who, based on his form criticism, dares to say that the entire content of the New Testament is a myth. Especially the stories about the Lord Jesus. He argued that the experiences of the Lord Jesus' ministry, His miracles, death, and resurrection, were stories made up by the early church. For him, modern humans cannot accept things that do not make sense, which are contrary to the current modern context. Modern humans cannot accept the supernatural and make it bound. Modern humans must be able to determine their own lives, without being influenced by things outside themselves, especially those that are irrational. The Bible, which has been filled with myths, should be reinterpreted, so that the gospel message can be presented correctly for modern humans.

\section{ACKNOWLEDGMENT}

The research contribution is as a reference for improving Christian faith, cannot accept unreasonable things.Bultmann's demythologization should not be taken as a theology, but as a discourse of seeking the truth with no clear origin, a thought for those who do not know God, namely vain thoughts, dark understanding. Thanks for Abdi Gusti Theological School that help this Articles was working out.

\section{REFERENCES}

[1] Morris Ashcraft. Maker of the Modern Theological Mind, Rudolf Bultman, (Texas: Word Book Publisher, 1972). p 15.

[2] M. Ashcraft, Maker of the Modern Theological Mind, Rudolf Bultman,Texas: Word Book Publisher, 1972.

[3] T. Lone,RuntutPijar,Jakarta: BPK GunungMulia, 1996.

[4] https://id.wikipedia.org/wiki/Rudolf_Bultmann, (Accessed on: 10 December 2017)

[5] F.D. Wellem. Riwayat Hidupsingkattokoh-tokohdalamsejarahGereja, Jakarta: BPK GunungMulia, 1998.

[6] L. Bagus, Kamus Filsafat, Jakarta: Gramedia Pustaka Utama, 2005.

[7] C. Wahyudi, "Eksistensialisme," JurnalTeosofi $2,374,2002$.

[8] https://claus08192222454.wordpress.com/2010/01/15/rudolfbultman-pit/, (Accessed on: 11 December 2017).

[9] https://fadlijafar.wordpress.com/2012/04/12/ rudolf-bultmann thoughts (Accessed on: 11 December2017).

[10] http://dangkalilmu.blogspot.co.id/2015/05/pemikiranhermeneutika-rudolf-karl.html,(Accessed on: 11 December 2017).

[11] F.D. Wellem, Riwayat Hidupsingkattokoh-tokohdalamsejarahGereja. 60.

[12] H. HadiwijonoTheologiReformatorisabadke 20,Jakarta: BPK GunungMulia, 1999.

[13] T. Lone. RuntutPijar, Jakarta: BPK GunungMulia, 1997.
[14] Hodern. Rudolf Bultman, New Testament and Mythology, London: Tyndale Press 1953.

[15] Ridderbos. Kerygma and Myth, London: Tyndale Press, 1953.

[16] C. Brown,Filsafat dan Iman Kristen, Jakarta: Lembaga Reformed Injili Indonesia, 1996.

[17] H.Hadiwijono. TheologiReformatorisabadke 20.

[18] Y. Moro. Transcendence and Imanence in Contemporary Theology: A ReportArticle, North East Asia Journal of Theology, 64, 196.

[19] H. M. Conn. TeologiKontemporer, Malang: SAAT, 1996.

[20] F.D. Wellem. Riwayat Hidupsingkattokoh-tokohdalamsejarahGereja. h 60 .

[21] H.Hadiwijono. TheologiReformatorisabadke 20, Jakarta: BPK GunungMulia, 1999.

[22] T. Lone. RuntutPijar, Jakarta: BPK GunungMulia, 1997.

[23] Hodern. Rudolf Bultman, New Testament and Mythology, London: Tyndale Press 1953.

[24] Ridderbos. Kerygma and Myth, London: Tyndale Press, 1953. 